\title{
Pengaruh Caring Climate, Kepuasan Kerja, Komitmen Organisasional dan Referent Power Terhadap Kinerja Karyawan
}

\author{
Yakobus Adi Nugroho ${ }^{1}$ \\ Monika Palupi Murniati ${ }^{2 *}$ \\ ${ }^{1,2}$ Universitas Katolik Soegijapranata \\ *Corresponding Author email: palupi@unika.ac.id
}

\begin{abstract}
Employees are an important element in an organization that determine the success of organization in fulfilling its goals and maintain the existence and the competitiveness of the organization. For these reasons, it is important to identify the factors that affect employee performance. This study examines the effect of caring climate, job satisfaction, and organizational commitment on job performance. As much as 85 respondents selected from college teacher and employee on university were employed for the test of hypothesis. This study uses Structural Equation Modeling analysis techniques with AMOS applications. The results show that caring climate has a direct effect on job satisfaction and organizational commitment. Direct effect can also be identified for the effect of job satisfaction on organizational commitment and job performance, and organizational commitment on performance. On the other hand, caring climate has an indirect on performance through job satisfaction. Job satisfaction cannot mediate the relationship between caring climate and organizational commitment. In addition, organizational commitment cannot mediate the relationship between job satisfaction and job performance.
\end{abstract}

Keywords: Caring Climate, Job Satisfaction, Organizational Commitment, And Job Performance

\begin{abstract}
Abstrak
Karyawan adalah elemen penting dalam suatu organisasi yang bisa menentukan tercapainya tujuan organisasi dan menjamin eksistensi serta daya saing organisasi. Karena itu penting untuk mengetahui faktor-faktor yang mempengaruhi kinerja karyawan. Penelitian ini bertujuan untuk menguji pengaruh iklim peduli, kepuasan kerja, dan komitmen organisasional terhadap kinerja. Sebanyak 85 responden dipilih dari dosen dan tenaga kependidikan di satu universitas untuk pengujian hipotesis. Penelitian ini juga menggunakan teknik analisis Structural Equation Modelling dengan aplikasi AMOS. Berdasarkan hasil pengujian data, ditemukan bahwa caring climate berpengaruh langsung terhadap kepuasan kerja dan komitmen organisasional. Pengaruh langsung juga terjadi pada kepuasan kerja terhadap komitmen organisasional dan kinerja, tetapi komitmen organisasional tidak berpengaruh langsung terhadap kinerja. Sedangkan pada pengaruh tidak langsung didapati bahwa caring climate berpengaruh pada kinerja melalui kepuasan kerja. Kepuasan kerja menjadi pemediasi antara hubungan caring climate terhadap komitmen organisasional. Kemudian, komitmen organisasional yang tidak dapat menjadi pemediasi antara hubungan kepuasan kerja terhadap kinerja, begitu juga caring climate terhadap kinerja karyawan.
\end{abstract}

Kata kunci: Caring Climate, Kepuasan Kerja, Komitmen Organisasional, dan Kinerja. 


\section{PENDAHULUAN}

Jumlah perguruan tinggi menurut data statistik PDDikti di setiap tahun menunjukkan pertambahan dari tahun 2017 sejumlah 4.498 menjadi 4.670 di tahun 2018 dan cenderung menurun di tahun 2019, sejumlah 4.621 (PDDikti, 2019). Daya saing di sektor pendidikan tinggi terletak pada sumber daya utama, yaitu peran dosen dan tenaga kependidikan yang memberikan jasa pelayanan pendidikan dan ketersediaan fasilitas yang mendukung proses pendidikan. Manajemen perguruan tinggi memiliki peran penting dalam mengelola dosen dan tenaga kependidikan agar mampu bekerja dan memberikan luaran yang dapat meningkatkan daya saing perguruan tinggi. Artinya, perilaku dosen dan tenaga kependidikan menjadi faktor penting dalam meningkatkan daya saing perguruan tinggi melalui kinerja luaran dalam jasa pelayanan pendidikan.

Penelitian ini mengadopsi model penelitian Fu dan Despande (2014) untuk menjelaskan pencapaian kinerja dengan variabel iklim peduli, kepuasan kerja dan komitmen organisasi di sektor pendidikan. Perguruan tinggi memiliki struktur dan hubungan kerja kolegial, yang berbeda dengan bentuk organisasi pada umumnya. Jenjang karir di perguruan tinggi ditentukan oleh kinerja akademik yang banyak dilakukan secara besama-sama, sehingga iklim peduli menjadi hal menarik untuk diuji kembali dalam sektor yang berbeda dengan penelitian sebelumnya. Validitas eksternal menjadi salah satu tujuan adopsi model penelitian Fu dan Despande (2014) dalam penelitian ini.

Iklim peduli merupakan salah satu bentuk dari iklim etis (Parboteeah et al., 2010). Iklim peduli menjelaskan pertimbangan etis individu yang didasarkan pada kepedulian kepada orang lain. Bentuk iklim etis ini tepat untuk digunakan dalam menjelaskan perilaku dosen dan tenaga kependidikan, dimana budaya bekerja secara tim dalam proses pengajaran, penelitian, pengabdian kepada masyarakat dan administrasi dalam perguruan tinggi sangat sering terjadi. Kepedulian terhadap ketercapaian tujuan pembelajaran, luaran dari kegiatan penelitian dan pengabdian kepada masyarakat dalam tim, menjadi bentuk iklim peduli yang nyata terjadi di perguruan tinggi. Tsai dan Cheng (2011) menyatakan bahwa organisasi yang memiliki iklim peduli tinggi akan memungkinkan terbentuknya perilaku rela membantu dan menolong individu lain yang sedang kesulitan, sehingga tujuan organisasi dapat dicapai dengan luaranluaran yang dihasilkan.

Iklim peduli yang tinggi dapat menciptakan suasana kerja yang terasa nyaman dan kondusif untuk bekerja. Beberapa penelitian menemukan bahwa iklim peduli berpengaruh terhadap kepuasan kerja (Okpara dan Wynn, 2008; Goldman dan Tabak, 2010, Meeusen et al., 2011 dan Dinc dan Plakalovic, 2016). Kepedulian antar individu dalam organisasi memberikan peluang bagi individu untuk saling membantu dalam proses belajar dan mengembangkan kemampuannya. Kondisi ini membuat individu memiliki persepsi yang positif terhadap pekerjaan yang dilakukannya.

Kepuasan kerja menjadi cara organisasi memberikan peran bagi individu dalam pencapaian tujuan organisasi. Fu et al., (2012) menyatakan bahwa kepuasan kerja memiliki dampak signifikan terhadap komitmen organisasi. Robbins dan Judge (2011) menjelaskan komitmen organisasi kekuatan individu dalam mengidentifikasikan keterlibatan dirinya dalam organisasi. Keterlibatan dapat tampak dari penerimaan nilai dan tujuan organisasi, kesediaan berusaha demi organisasi dan keinginan mempertahankan keanggotaan dalam organisasi. Dengan kata lain, komitmen organisasi adalah keterikatan karyawan dengan organisasi untuk membantu atau berkontribusi organisasi dalam mencapai tujuan-tujuannya. Karyawan yang mempunyai komitmen organisasi yang tinggi dalam perkerjaanya akan memberikan 
kemampuan yang terbaik dalam setiap pekerjaannya. Maka itu, organisasi harus memberikan kenyamanan pada karyawan agar memiliki keterikatan dengan organisasi.

Penelitian ini mengembangkan model penelitian yang diadopsi dari Fu dan Deshpande (2014) dengan menambahkan variabel baru yang direkomendasikan, yaitu social power. French dan Reaven dalam Biong et al. (2010) menyatakan ada lima bentuk social power, yaitu 1) coercive power, 2) reward power, 3) referent power, 4) expert power, dan 5) legitimate power. Pada penelitian ini, bentuk social power yang akan ditambahkan sebagai variabel penelitian adalah referent power. Referent power merupakan power pimpinan yang terbentuk karena perilaku pemimpin yang dipersepsikan positif oleh bawahannya. Perilaku disiplin, ketaatan pada peraturan, jujur, respek terhadap bawahan dan kepribadian baik yang dimiliki oleh pemimpin, membentuk karisma yang memiliki kekuatan untuk mengatur dan mempengaruhi bawahannya. Konsep ini dapat diimplementasikan dalam perguruan tinggi, dimana perilaku pimpinan dalam kegiatan akademik, pembuatan keputusan dan kepribadian pemimpin akan menjadi referensi para dosen dan tenaga kependidikan untuk memiliki perilaku tertentu yang diatur dan diarahkan oleh pimpinan. Peran penting pemimpin dalam sebuah organisasi untuk mengarahkan semua sumber daya dalam mencapai tujuan, menjadi argumentasi pentingnya variabel ini dalam model penelitian Fu dan Despande (2014).

\section{TINJAUAN LITERATUR DAN PERUMUSAN HIPOTESIS}

\section{Kinerja Karyawan}

Menurut Supardi (2013) kinerja adalah prestasi dari suatu kegiatan yang telah dibebankan. Pengertian kinerja sering diidentikkan dengan prestasi kerja karena persamaan antara kinerja dengan prestasi kerja. Kinerja lebih sering disebut dengan prestasi yang merupakan 'hasil' atau 'apa yang keluar' (outcomes) dari sebuah pekerjaan dan kontribusi sumber daya manusia terhadap organisasional. Kinerja adalah hasil pekerjaan yang dicapai seseorang berdasarkan persyaratan-persyaratan pekerjaan (Bangun, 2012). Suatu pekerjaan mempunyai persyaratan tertentu untuk dapat dilakukan dalam mencapai tujuan yang disebut juga sebagai standar pekerjaan. Menurut Umam (2012), kinerja adalah catatan mengenai akibat-akibat yang dihasilkan pada sebuah fungsi pekerjaan atau aktivitas selama periode tertentu yang berhubungan dengan tujuan organisasi. Sedangkan, menurut Mangkunegara (2009) kinerja adalah hasil kerja secara kualitas dan kuantitas yang dicapai oleh seorang pegawai dalam melaksanakan tugasnya sesuai dengan tanggung jawab yang diberikan kepadanya.

Terdapat tiga kreteria dalam penilaian kinerja: 1) Kriteria berdasarkan sifat. Kriteria ini berpusat pada karakteristik pribadi setiap karyawan. 2) Kriteria berdasarkan perilaku. Kriteria berdasarkan perilaku ini mengarah pada bagaimana suatu pekerjaan dilaksanakan dengan baik. 3) Kriteria berdasarkan jenis. Kriteria jenis ini mengarah pada pencapaian hasil pekerjaan (Bangun, 2012).

\section{Iklim Peduli}

Iklim peduli adalah salah satu dimensi dalam iklim etis. Parboteeah et al. (2010) meneliti bahwa iklim etis dibagi ke dalam lima dimensi, yaitu iklim peduli (caring climate), law \& code climate, rules climate, instrumental climate, dan independent climate. Iklim etis adalah persepsi bersama tentang bagaimana masalah etika harus ditangani dan perilaku apa 
yang benar secara etis (Fu and Deshpande, 2014). Dalam organisasi, iklim etis ini sangat penting karena dapat mempengaruhi kinerja karyawan. Iklim etis berhubungan dengan etika karyawan dalam bekerja. Jadi, iklim etis yang baik dalam sebuah organisasi akan berdampak dalam etika karyawan dalam pekerjaannya.

Iklim peduli berfokus pada kebajikan etis kriteria dan didasarkan pada kepedulian terhadap orang lain (Tsai and Chen, 2011). Sedangkan, menurut Laratta (2009) bahwa karyawan yang memiliki iklim peduli diharapkan untuk peduli terhadap orang lain serta karyawan memiliki ketulusan terhadap kesejahteraan orang lain, baik itu di dalam atau di luar perusahaan. Dengan adanya iklim peduli setiap karyawan memiliki kepedulian terhadap orang lain yang ada di organisasi sehingga akan menciptakan suasana yang nyaman dalam bekerja. Karyawan yang memiliki kepedulian terhadap rekan kerjanya sangat menguntungkan bagi perusahaan. Karyawan tersebut akan membantu rekan kerjanya yang sedang kesulitan menyelesaikan tugasnya sehingga akan menguntungkan perusahaan dan dirinya sendiri. Dengan adanya karyawan yang saling tolong-menolong akan menciptakan suasana kerja yang nyaman. Bekerja dengan suasana yang nyaman akan meningkatkan kefokusan karyawan dalam pekerjaannya sehingga akan meningkatkan kinerja karyawan itu sendiri.

\section{Kepuasan Kerja}

Menurut Sutrisno (2012), kepuasan kerja karyawan merupakan masalah penting yang diperhatikan dalam hubungannya dengan produktivitas kerja karyawan dan ketidakpuasan sering dikaitkan dengan tingkat tuntutan dan keluhan pekerjaan yang tinggi. Kepuasan kerja tercermin dari sikap karyawan dalam melakukan tanggung jawab dan tugasnya. Karyawan yang tidak puas dengan pekerjaannya akan memberikan sikap negatif seperti malas bekerja, tidak disiplin, sering mengeluh tentang pekerjaannya. Karyawan yang tidak puas dengan pekerjaanya dapat menghambat organisasi dalam mencapai tujuan yang telah ditentukan. Perusahaan harus memberikan hukuman dan perhatian yang lebih terhadap karyawan seperti itu agar karyawan tersebut dapat lebih baik lagi dalam bekerja.

Kepuasan kerja sebagai perasaan positif pada suatu pekerjaan, yang merupakan dampak atau hasil evaluasi dari berbagai aspek pekerjaan tersebut (Robbins dan Judge, 2011). Kepuasan kerja merupakan penilaian dan sikap seseorang atau karyawan terhadap pekerjaannya dan berhubungan dengan lingkungan kerja, jenis pekerjaan, hubungan antar teman kerja, dan hubungan sosial di tempat kerja. Secara sederhana kepuasan kerja atau job satisfaction dapat disimpulkan sebagai apa yang membuat seseorang menyenangi pekerjaan yang dilakukan karena mereka merasa senang dalam melakukan pekerjaannya.

Menurut Robbins (2010) terdapat indikator yang dapat digunakan untuk mengukur kepuasan sebagai berikut: 1) kepuasan dengan gaji, bila upah dilihat adil yang didasarkan pada tuntutan pekerjaan, tingkat keterampilan individu, dan standar pengupahan komunitas, kemungkinan besar akan menghasilkan kepuasan, 2) kepuasan dengan promosi, kepuasan akan dapat berkembang melalui kenaikan jabatan. Seseorang akan dapat merasakan adanya kemungkinan yang besar untuk naik jabatan atau tidak, proses kenaikan jabatan kurang terbuka atau terbuka, 3) kepuasan dengan rekan kerja, karyawan mendapatkan lebih dari sekedar uang atau prestasi yang terwujud dari mereka dan kebanyakan merupakan kerja yang membutuhkan interaksi social, 4) Kepuasan dengan atasan, cara-cara atasan dapat tidak menyenangkan bagi bawahannya atau menyenangkan dan hal ini dapat mempengaruhi kepuasan seseorang, 5) kepuasan dengan pekerjaan itu sendiri, para karyawan lebih menyukai pekerjaan-pekerjaan yang memberi mereka kesempatan untuk mempergunakan keterampilan dan kemampuan mereka sendiri. 


\section{Komitmen Organisasional}

Komitmen organisasional merupakan kemauan, kesetiaan, loyalitas karyawan terhadap organisasi. Karyawan yang memiliki komitmen, bersedia untuk bertanggung jawab dan ikut terlibat dalam pencapaian tujuan organisasi. Selain itu, karyawan tidak akan memiliki niat untuk berhenti atau keluar dari pekerjaannya. Komitmen organisasional didefinisikan sebagai kekuatan yang bersifat relatif dari individu dalam mengidentifikasikan keterlibatan dirinya kedalam bagian organisasi, yang dicirikan oleh penerimaan nilai dan tujuan organisasi, kesediaan berusaha demi organisasi dan keinginan mempertahankan keanggotaan dalam organisasi (Robbins and Judge, 2011).

Menurut Mathis dan Jackson (2010) komitmen organisasional adalah di mana karyawan yakin dan menerima tujuan organisasional, serta berkeinginan untuk tinggal bersama organisasi tersebut. Dengan karyawan menerima tujuan organisasi, karyawan akan berusaha dengan kemampuannya untuk mencapai tujuan organisasi. Organisasi harus menyampaikan tujuan organisasi dengan jelas kepada karyawan agar karyawan mengerti sehingga tujuan organisasi lebih mudah tercapai.

\section{Referent Power}

Referent power merupakan salah satu bagian dari social power. Sementara faktor social power terbagi lima yaitu (1) coercive power, (2) reward power, (3) referent power, (4) expert power, dan (5) legitimate power (Biong et al., 2010). Referent power adalah kekuatan yang berkaitan seberapa besar seseorang ingin mereferensikan dirinya dengan suatu yang dikagumi. Kemampuan ini berkembang dari kekaguman satu pihak serta keinginan dari pihak pengagum untuk menjadi seperti yang dikagumi. Sesuatu yang direferensikan oleh orang memiliki karakteristik yang positif sehingga menjadi referensi bagi orang lain. Proses identifikasi ini didasarkan pada persepsi orang yang mengindentifikasi orang lain bahwa perilaku orang lain yang diidentifikasi memiliki beberapa kesamaan dengan dirinya atau ingin meniru sikap atau perilaku orang lain untuk dirinya sendiri.

Referent power menurut Kudisch et al., (2010) adalah kecenderungan seseorang untuk mematuhi yang dikagumi karena dia mengagumi atau ingin mereferensikan dengan yang dikaguminya. Di dalam organisasi, referent power ini digunakan karyawan untuk mendapat imbalan dari pemimpinnya seperti kenaikan jabatan, gaji, dan bonus. Dengan begitu, pemimpin mudah dalam dalam mengontrol karyawannya karena pemimpin tersebut memiliki power yang timbul dari karyawan yang mereferensikan pemimpin tersebut sehingga karyawan tersebut dengan sukarela mengikuti perintah pemimpinnya dalam mencapai tujuan organisasionalnya.

\section{Iklim Peduli, Kepuasan kerja, dan Komitmen Organisasional.}

Laratta (2009) bahwa iklim peduli dalam suatu organisasi memungkinkan individu untuk memiliki perilaku peduli terhadap kesejahteraan individu lain dan organisasi. Sikap saling peduli antar karyawan ini akan menumbuhkan sikap saling tolong-menolong rekan kerja yang sedang kesulitan. Iklim peduli menciptakan peluang bagi para dosen dan tenaga kependidikan untuk terlibat dalam proses pembelajaran yang berkaitan dengan tugas-tugas mereka. Kemampuan yang berkembang dalam proses pembelajaran ini akan membantu dosen dan tenaga kependidikan dalam melaksanakan tugas mereka dengan baik. Kenyamanan dan kemampuan dalam bekerja akan membuat mereka bersedia tinggal di organisasi. Kemampuan dan keterlibatan dosen dan tenaga kependidikan dalam pencapaian kinerja organisasi akan 
menumbuhkan keterikatan mereka dengan organisasi. Keterikatan ini membentuk komitmen dosen dan tenaga kependidikan pada organisasi.

Hubungan iklim peduli terhadap komitmen melalui kepuasan kerja ini didukung oleh temuan penelitian sebelumnya. Okpara dan Wynn (2012) menemukan bahwa iklim peduli memiliki dampak positif yang signifikan terhadap kepuasan kerja secara keseluruhan dan berbagai aspek kepuasan kerja termasuk promosi, pengawasan, rekan kerja, dan pekerjaan itu sendiri. Temuan Fu \& Deshpande (2014) menyatakan bahwa kepuasan kerja memiliki dampak yang signifikan terhadap komitmen organisasi. Berdasarkan diskusi di atas maka hipotesis pertama dapat dirumuskan sebaga berikut:

\section{H1: Iklim peduli memiliki pengaruh tidak langsung terhadap komitmen organisasional melalui kepuasan kerja.}

\section{Iklim peduli, Kepuasan Kerja, dan Kinerja}

Iklim peduli dalam suatu organisasi dapat dideskripsikan sebagai suasana bekerja yang memikirkan individu lain dalam setiap pengambilan keputusan. Perilaku individu yang peduli pada kemampuan dan capaian individu lain yang mendukung organisasi, menjadi bagian dalam proses belajar dan bekerja. Perhatian yang diberikan oleh dosen atau tenaga kependidikan lain dalam pekerjaan menjadi bentuk respek yang memberikan rasa nyaman. Bantuan yang diterima dalam proses pembelajaran dan pekerjaan membuat dosen dan tenaga kependidikan memiliki kemampuan untuk bekerja dengan lebih baik. Peningkatan kemampuan ini berpengaruh pada capaian kinerja dosen dan tenaga kependidikan. Individu yang memiliki sikap puas terhadap pekerjaannya akan menunjukkan sikap yang positif terhadap kerja tersebut

Sikap saling peduli akan menumbuhkan sikap saling tolong-menolong antar rekan kerja yang sedang kesulitan. Perhatian yang diberikan oleh rekan kerja memberikan rasa nyaman dalam bekerja. Sikap positif itu ditunjukkan dengan bekerja dengan sunguh-sungguh untuk mencapai target yang ditetapkan perusahaan, sehingga perusahaan akan menilai karyawan tersebut memiliki kinerja yang sangat baik.

Hipotesis ini didukung oleh penelitian dari Fu and Deshpande (2014) yang menemukan bahwa responden dengan organisasi yang memiliki iklim peduli dengan peran pengawas yang sangat membantu mengendalikan aktivitas pencapaian tujuan, memiliki kepuasan kerja dan kinerja yang baik. Saragih (2018) menemukan adanya kepuasan kerja berpengaruh positif terhadap kinerja karyawan dan temuan Yuliana (2009) yang menyatakan terdapat pengaruh positif dan signifikan kepuasan kerja terhadap kinerja karyawan. Berdasarkan diskusi di atas maka hipotesis kedua dapat dirumuskan sebaga berikut:

\section{H2: Iklim peduli memiliki pengaruh tidak langsung terhadap kinerja melalui kepuasan kerja.}

\section{Iklim peduli, Komitmen Organisasional, dan Kinerja}

Fu dan Despande (2012) menemukan bahwa iklim peduli memiliki pengaruh paling besar dibandingkan dengan bentuk iklim etis lain, terhadap perilaku karyawan. Pertimbangan yang memiliki fokus terhadap apa yang baik bagi setiap individu dalam organisasi, merupakan argumentasi utama mengapa individu dalam organisasi memiliki perilaku positif. Bukan kode etik yang menjadi cara untuk membuat individu berperilaku positif, tetapi 
perlakuan individu satu terhadap individu lain yang mempengaruhi efektifitas kerja dalam organisai. Perlakuan individu yang memberikan kesempatan berkembang dengan membantu kesulitan-kesulitan yang ditemui individu lain, menumbuhkan keterikatan individu dengan organisasi. Dalam perguruan tinggi, mentoring menjadi bentuk implementasi dari iklim peduli, yaitu ketika senior memberikan pendampingan dalam proses pengajaran, penelitian dan pengabdian kepada masyarakat. Bagi tenaga kependidikan, interaksi dan kebutuhan saling melengkapi antar peran administrasi, menjadi cara untuk saling peduli dan memberikan bantuan untuk mencapai kinerja yang baik. Proses ini membentuk keterikatan dosen dan tenaga kependidikan pada perguruan tinggi, sehingga mereka akan memberikan kemampuan terbaik bagi organisasinya. Hipotesis ini didukung oleh temuan Riaz (2010), Dewi (2017) dan Rosyidah (2018) yang menyatakan bahwa ada hubungan positif antara komitmen organisasi dan kinerja kerja karyawan. Berdasarkan diskusi di atas maka hipotesis ketiga dapat dirumuskan sebaga berikut:

\section{H3: Iklim peduli memiliki pengaruh tidak langsung terhadap kinerja melalui komitmen organisasional.}

\section{Kepuasan Kerja, Komitmen Organisasional, dan Kinerja}

Individu yang merasa nyaman dan puas terhadap pekerjaan yang dilakukan cenderung akan mempertahankan posisinya untuk tetap berada di dalam organisasi. Konsekuensi terhadap capaian kinerja akan berpengaruh terhadap capaian kinerja individu selanjutnya, sehingga kepuasan terhadap pekerjaan saat ini menjadi alasan individu untuk tetap tinggal dalam organisasi. Kemampuan individu akan membuat perasaan nyaman dan yakin bahwa dirinya mampu melakukan pekerjaannya dengan baik, sehingga merasa puas dengan luaran yang dihasilkan. Konsekuensi luaran yang baik akan membentuk komitmen individu untuk tetap tinggal dalam organisasi dengan cara tetap memiliki capaian kinerja yang baik.

Keterikatan individu dengaan organisasi merupakan hal yang memberikan benefit bagi bagi organisasi tersebut. Individu yang memiliki ketergantungan terhadap organisasi akan memberikan kemampuan terbaik untuk pencapaian kinerja yang terbaik pula. Hipotesis ini didukung oleh penelitian dari Fu et al. (2011) yang menemukan bahwa aspek kepuasan kerja (gaji, rekan kerja, pengawasan, dan pekerjaan itu sendiri) memiliki dampak yang signifikan terhadap komitmen organisasi. Jamal (2011) dan Ratna (2017) menemukan bahwa komitmen organisasi berpengaruh signifikan terhadap kinerja. Berdasarkan diskusi di atas maka hipotesis keempat dapat dirumuskan sebaga berikut:

\section{H4: Kepuasan kerja memiliki pengaruh tidak langsung terhadap kinerja melalui Komitmen organisasional.}

\section{Referent Power dan Kepuasan Kerja.}

Biong et al., (2010) menjelaskan referent power sebagai kekutan pemimpin yang dibentuk dari perilaku positif yang dimiliki oleh pemimpin. Personaliti dan karisma yang dimiliki pemimpin menjadi sumber bagi terbentuknya power. Perilaku baik dari pemimpin akan membuat bawahan taat terhadap perintah dan arahan pimpinan. Dalam hal ini terjadi perilaku pimpinan menjadi referensi bagi perilaku bawahan untuk berperilaku serupa. Figur pemimpin menjadi jaminan kepastian bahwa perilaku individu dalam organisasi akan terkoordinasi dengan baik. Kekuatan dan kemampuan pemimpin untuk mengarahkan bawahan dalam upaya pencapaian tujuan menjadi lebih mudah. Kondisi ini akan memberikan rasa 
nyaman dan yakin akan kemampuan individu yang diarahkan oleh pemimpin untuk mencapai tujuan.

Dalam ranah perguruan tinggi, perilaku pimpinan positif dalam bidang akademik dan pengambilan keputusan terhadap permasalahan akademik dan non akademik akan menjadi referensi bagi dosen dan tenaga kependidikan dalam berperilaku. Keberhasilan pimpinan menjadi best practice bagi bawahannya akan membuat pemimpin mampu mengarahkan dan memberikan perintah tentang apa yang harus dilakukan bawahan untuk aktivitas pencapaian tujuan. Kepastian terhadap aktivitas ini bisa tampak pada terencananya program kerja, pengendalian yang baik dalam proses penyelenggaraan pendidikan dan indikator kinerja yang jelas dan dapat diterima oleh bawahan, akan membentuk pemahaman dosen dan tenaga kependidikan mengenai apa yang harus dilakukan. Pemahaman mengenai apa yang harus dilakukan akan membuat dosen dan tenaga kependidikan merasa nyaman dan menguasahakan yang diperlukan untuk dapat pekerjaannya dengan baik. Kepastian ini yang membuat dosen dan tenaga kependidikan untuk tetap tinggal dalam organisasinya. Valentine dan Barnett (2003) menyatakan bahwa pemimpin memiliki fungsi sebagai ethical role model dalam membentuk perilaku positif bawahannya. Referent power menjadi penjelas bagaimana pemimpin berperan sebagai role model dan membuat role model tersebut sebagai sumber power untuk menggerakkan perilaku bawahannya. Berdasarkan diskusi di atas maka hipotesis kelima dapat dirumuskan sebaga berikut:

H5: Referent power memiliki pengaruh terhadap kepuasan kerja.

\section{METODE PENELITIAN}

\section{Populasi dan Sampel}

Populasi yang akan diteliti dalam penelitian ini adalah seluruh dosen dan karyawan di sebuah universitas swasta Jawa Tengah yang berjumlah 448 orang. Penentuan jumlah sampel dalam penelitian ini diambil dengan rumus slovin. Menghitung sampel dengan rumus:

$$
\mathrm{n}=\frac{N}{1+N e^{2}}
$$

$$
\begin{gathered}
\mathrm{n}=\frac{448}{1+448 \times 0.10^{2}} \\
\mathrm{n}=81 \text { orang. }
\end{gathered}
$$

Keterangan: $\mathrm{n}=$ Sampel, $\mathrm{N}=$ Populasi, $\mathrm{Ne}=$ tingkat toleransi

Berdasarkan perhitungan diatas, peneliti harus mengumpulkan sampel dengan jumlah 81 orang atau lebih karena penelitian ini menggunakan tingkat toleransi sebesar $10 \%$. Penyebaran kuesioner dilakukan dengan mendatangi langsung tenaga kependidikan dan tenaga pengajar dengan memberikan lembaran kuesioner yang berisi pernyataan-pernyataan. Tabel 1 menyajikan prosedur pemilihan responden. 
Tabel 1. Pemilihan Sampel

\begin{tabular}{clc}
\hline No & Keterangan & Jumlah \\
\hline 1 & Penyebaran Kuesioner ke Tenaga Kependidikan & 59 \\
2 & Penyebaran Kuesioner ke Dosen & 37 \\
3 & Eliminasi outlier & 11 \\
Kuesioner yang dapat digunakan sebagai sampel & 85 \\
\hline
\end{tabular}

Pada tabel 1 dapat dilihat bahwa terdapat 96 orang yang menjadi responden yang terdiri dari 59 orang tenaga kependidikan dan 37 tenaga pengajar. Akan tetapi, dalam pengolahan data terdapat 11 yang terindikasi sebagai outlier, maka dari itu harus dikeluarkan dari penelitian. Sehingga jumlah sampel adalah 85 orang dengan 50 orang tenaga kependidikan dan 35 orang tenaga pengajar.

\section{Pengukuran Variabel}

\section{Kinerja}

Variabel dependen dalam penelitian ini adalah kinerja. Definisi operasional dari kinerja adalah seberapa baik hasil kinerja seseorang yang dinilai oleh dirinya sendiri, atasan, dan rekan kerja. Pengukuran kinerja karyawan ini menggunakan instrument $\mathrm{Fu}$ and Deshpande (2014) dengan menggunakan skala linkert 5 poin. Semakin tinggi skor maka semakin tinggi pula kinerja.

\section{Iklim Peduli}

Iklim peduli adalah iklim organisasi yang menekankan pada kesejahteraan bagi semua orang yang ada di organisasional. Pengukuran variabel iklim peduli menggunakan instrumen yang dikembangkan Fu and Deshpande (2014) menggunakan skala linkert 5 poin. Semakin tinggi skor maka semakin tinggi pula iklim organisasi yang mempertimbangkan kesejahteraan orang lain.

\section{Kepuasan Kerja}

Kepuasan kerja adalah keinginan tetap bekerja dan kepuasan terhadap pekerjaannya. Pengukuran variabel kepuasan menggunakan instrumen yang dikembangkan $\mathrm{Fu}$ and Deshpande (2014) dengan menggunakan skala linkert 5 poin. Semakin tinggi skor maka semakin tinggi pula kepuasan kerja.

\section{Komitmen Organisasional}

Komitmen organisasional adalah keterikatan dan ketergantungan karyawan dengan organisasi. Pengukuran variabel ini menggunakan instrumen yang dikembangkan Thomas (2013) yang terdiri dari tiga dimensi, yaitu komitmen afektif, komitmen keberlanjutan, dan komitmen normatif. Komitmen organisasional diukur menggunakan skala linkert 5 poin. Semakin tinggi skor semakin tinggi pula komitmen organisasional. 


\section{Referent Power}

Referent power adalah perilaku atasan yang mampu mempengaruhi dan membuat responden mengidentifikasi dirinya dengan universitas. Pengukuran variabel ini menggunakan instrumen yang dikembangkan Biong et al. (2010) dengan lima skala linkert. Semakin tinggi skor maka semakin tinggi pula perilaku atasan yang membuat dosen dan tenaga kependidikan mereferensikan dirinya dengan universitas.

\section{Model Penelitian}

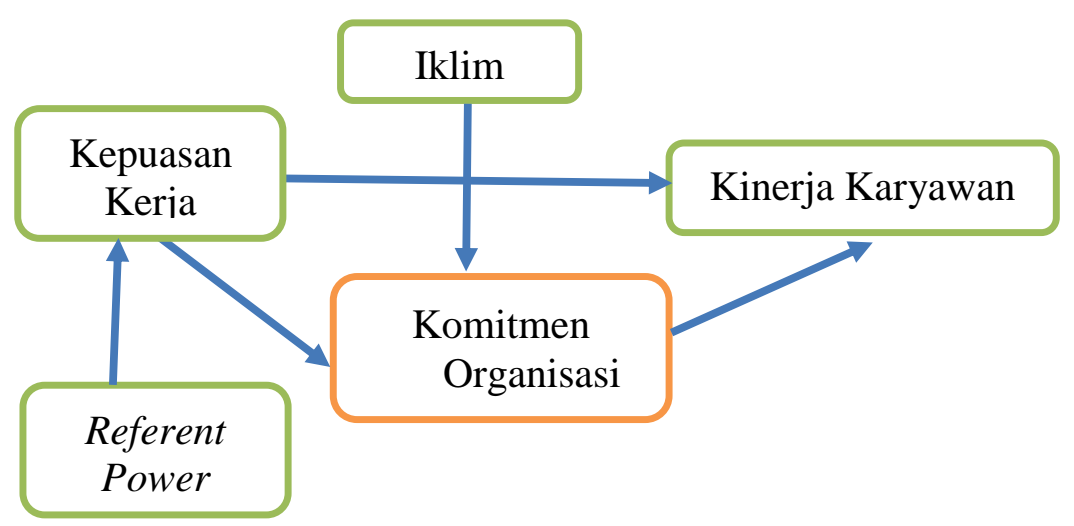

\section{Gambar 1. Model Penelitian}

Model penelitian ini menguji pengaruh referent power dan peran mediasi kepuasan kerja dan komitmen organisasi pada hubungan iklim peduli terhadap kinerja karyawan. Pemimpin dengan atribut karisma dan perilaku positif menjadi sumber kekuatan untuk mempengaruhi perilaku dosen dan tenaga kependidikan dalam usaha mencapai tujuan. Bawahan yang memiliki pemahaman jelas mengenai apa yang harus dikerjakan dan dicapai dalam pekerjaannya akan merasa puas dan cenderung mempertahankan keberadaannya dalam organisasi. Iklim peduli memberikan peluang bagi setiap dosen dan tenaga kependidikan untuk mendapatkan bantuan dalam proses mengembangkan kemampuan dirinya. Kepedulian dalam proses pengajaran, penelitian dan pengabdian kepada masyarakat serta pemenuhan kebutuhan administrasi dalam pengambilan keputusan memberikan jaminan bahwa segala aktivitas dapat dikerjakan dengan baik, sehingga masing-masing dosen dan tenaga kependidikan merasakan puas terhadap pekerjaannya. Kepuasan kerja yang memberikan kenyamanan dan konsekuensi yang memberikan benefit bagi individu, akan membentuk keterikatan individu dengan universitas. Keterikatan dosen dan karyawan pada universitas mendorong perilaku positif dalam bidang pekerjaan dosen dan tenaga kependidikan, sehingga mereka memiliki kinerja yang baik

\section{HASIL DAN PEMBAHASAN}

\section{Statistik Deskriptif}

Statistik deskriptif merupakan statistik yang menggambarkan mengenai karakteristik dari masing-masing variabel penelitian sehingga dapat diperoleh gambaran secara umum tentang kondisi dari sampel yang di teliti. Dalam penelitian ini diperoleh data sebanyak 96 observasi dengan periode waktu penelitian tahun 2019. 
Hasil chi-square menunjukkan adanya distribusi tidak normal karena nilai probabilitas awal kurang dari 0,05. Untuk menormalkan data tersebut maka dihapus sebanyak 11 data yang ekstrim sehingga didapat 85 data. Berikut ini adalah tabel statistik deskriptif 85 data. Pada tabel 2 ini, tidak disertakan hasil uji beda dari masing-masing variabel penelitian menurut identitas responden, tetapi uji tersebut telah dilakukan dan akan dijelaskan pada bagian di bawah ini. Berdasarkan tabel 2, dapat disimpulkan bahwa data ini terdiri dari 85 responden. Dari segi jenis kelamin terdapat 48 responden laki-laki dan 37 responden perempuan. Dari segi umur, terdiri 29 responden untuk umur 20 tahun sampai 35 tahun, 36 responden untuk umur 36 tahun sampai 50 tahun, dan 20 responden untuk umur 50 tahun sampai 63 tahun. Dari segi lama bekerja, terdapat 38 responden yang bekerja kurang dari 10 tahun, 32 responden yang bekerja dari 11 tahun sampai 25 tahun, dan 15 responden yang bekerja dari 26 tahun sampai 35 tahun. Dari segi pendidikan, teridiri 17 responden yang menempuh pendidikan sampai SMA, 8 responden yang menempuh pendidikan sampai D3, 24 responden yang menempuh pendidikan sampai S2, dan 13 responden yang menempuh pendidikan sampai S3. Serta dari segi pekerjaan, terdapat 50 responden yang bekerja sebagai tanaga kependidikan, dan 35 responden yang bekerja sebagai tenaga pengajar. Rata-rata dari semua demografi responden memiliki skor yang tinggi karena rata-ratanya berada diatas dari nilai 3,01 .

Dari demografi umur dan lama bekerja responden, referent power memiliki nilai signifikansi 0,04 dan 0,072, sehingga dapat diartikan ada perbedaan antara responden yang memiliki umur dari 20 - 35 tahun, 36 - 50 tahun, dan 50 - 63 tahun dan lama bekerja 1-10 tahun, 11-25 tahun dan 26-35 tahun mengenai referent power. Sedangkan variabel iklim peduli, kepuasan kerja, komitmen organisasional dan kinerja karyawan tidak berbeda signifikan menurut umur dan lama bekerja. Menurut tingkat pendidikan, responden memiliki perbedaan keinginan untuk tetap bekerja dan keterikatan dengan organisasi. Sedangkan untuk variabel referent power, iklim peduli dan kinerja, responden tidak memiliki perbedaan menurut tingkat pendidikan.

Tabel 2. Statistik Deskriptif

\begin{tabular}{cccccccc}
\hline Keterangan & Jumlah & $\begin{array}{c}\text { Rerata } \\
\text { Caring } \\
\text { Climate }\end{array}$ & $\begin{array}{c}\text { Rerata } \\
\text { Kepuasan } \\
\text { Kerja }\end{array}$ & $\begin{array}{c}\text { Rerata } \\
\text { Komitmen } \\
\text { Organisasional }\end{array}$ & $\begin{array}{c}\text { Rerata } \\
\text { Referent } \\
\text { Power }\end{array}$ & $\begin{array}{c}\text { Rerata } \\
\text { Kinerja }\end{array}$ \\
\hline $\begin{array}{c}\text { Jenis } \\
\text { Kelamin }\end{array}$ & Laki-laki & 48 & 4,62 & 4,20 & 4,39 & 4,04 & 4,13 \\
& Perempuan & 37 & 4,32 & 3,89 & 4,13 & 3,86 & 3,91 \\
Umur & 20-35 Th & 29 & 4,45 & 4,05 & 4,39 & 3,86 & 4,05 \\
& $50-63 \mathrm{Th}$ & 36 & 4,47 & 4,11 & 4,26 & 3,97 & 4,04 \\
Lama & $0-10 \mathrm{Th}$ & 38 & 4,45 & 4,07 & 4,37 & 3,91 & 4,01 \\
Bekerja & $11-25 \mathrm{Th}$ & 32 & 4,56 & 4,05 & 4,19 & 3,95 & 4,05 \\
& $26-35 \mathrm{Th}$ & 15 & 4,47 & 4,10 & 4,20 & 4,13 & 4,07
\end{tabular}




\begin{tabular}{cccccccc}
\hline \multirow{4}{*}{ Pendidikan } & SMA & 17 & 4,41 & 4,12 & 4,25 & 4,00 & 3,98 \\
& D3 & 8 & 4,38 & 3,50 & 3,86 & 3,88 & 3,67 \\
& S1 & 24 & 4,42 & 4,15 & 4,42 & 3,92 & 4,17 \\
& S2 & 23 & 4,61 & 4,17 & 4,29 & 4,00 & 4,07 \\
& S3 & 13 & 4,62 & 4,00 & 4,27 & 4,00 & 4,03 \\
& Tenaga & 50 & 4,46 & 4,02 & 4,27 & 3,94 & 4,05 \\
& Kependidikan & & & & & & \\
& $\begin{array}{c}\text { Tenaga } \\
\text { Pengajar }\end{array}$ & 35 & 4,54 & 4,13 & 4,28 & 4,00 & 4,03
\end{tabular}

Sumber: Data primer yang diolah (2019)

\section{Hasil Pengujian Hipotesis}

Sebelum melakukan pengujian hipotesis, data penelitian ini harus di uji normalitas, validitas, reliabilitas dan goodness of fit. Hal ini dilakukan agar data yang diolah dapat diandalkan, memiliki tingkat fit yang bagus dan berdistribusi normal. Tabel 3 menyajikan hasil pengolahan data.

Berdasarkan tabel 3 terdapat 10 pernyataan yang tidak valid karena nilai estimasi kurang dari 0,5 yaitu KK1, KO15, KO12, KO11, KO 10, KO9, KO7, KO5, KO4, KO3. Pada tabel 3, hanya pernyataan yang valid yang dicantumkan. Pernyataan yang valid tersisa 14 yaitu KK2, KK3, KO14, KO13, KO8, KO6, KO2, KO1, Kinerja1, Kinerja2, Kinerja3, RP1, RP2, CC. Pernyataan $\mathrm{CC}$ ini, tidak memiliki nilai estimate karena dalam satu variabel hanya memiliki satu pernyataan.

Berdasarkan tabel 3 semua variabel memiliki data yang reliabel dengan nilai reliabilitas konstruk lebih dari 0,500. Sedangkan untuk variabel iklim peduli tidak memiliki nilai reliabilitas konstruk karena hanya memiliki satu pernyataan. Nilai c.r. skew dan c.r. kurtosis dari semua variabel memiliki nilai diantara $\pm 2,58$, sehingga dapat disimpulkan bahwa semua data variabel berdistribusi normal dan pengujian hipotesis menggunakan statistik parametik dapat dilakukan.

Model penelitian ini memiliki nilai likelihood chi-square sebesar 0.054. Menurut Ghozali (2017) menyarankan suatu data dapat dikatakan sesuai dengan teori/model atau nilai signifikan tinggi apabila nilai probability chi-square $>0.05$. Nilai CMIN/DF sebesar 1,388 , menurut Gozhali (2017) bahwa nilai yang kurang dari 5 merupakan ukuran yang dikatakan reasonable. Comparatif Fit Index memiliki nilai sebesar 0.957, menurut Gozhali (2017) diharapkan nilainya lebih dari atau sama dengan 0,90. Root Mean Square Error of Approximation (RMSEA) memiliki nilai sebesar 0.058, menurut Ghozali (2017) sebuah model dapat dikatakan fit dan dapat diterima apabila nilai RMSEA $<0.08$. GFI (goodness of fit index) memiliki nilai sebesar 0.878, menurut Ghozali (2017) nilai GFI > 0,90 mengisyaratkan model yang diuji memiliki kesesuaian yang baik. Incremental Fit Index (IFI) memiliki nilai sebesar 0.959, menurut Ghozali (2017) nilai IFI >0,90 mengisyaratkan bahwa model tidak mengalami masalah parsimoni dan ukuran sampel. Tucker Levis Index (TLI) memiliki nilai sebesar 0.949, menurut Ghozali (2017) nilai TLI < 0,90 yang dapat diterima. 
Berdasarkan hasil tersebut terdapat 6 indikator yang menyatakan model penelitian ini fit, jadi dapat dikatakan model penelitian ini fit.

Tabel 3. Hasil Uji Keandalan Data

\begin{tabular}{|c|c|c|c|c|c|c|}
\hline Keterangan & Estimasi & $\begin{array}{l}\text { C.R. } \\
\text { Skew }\end{array}$ & $\begin{array}{c}\text { C.R. } \\
\text { Kurtosis }\end{array}$ & Keterangan & $\begin{array}{l}\text { Reliabilitas } \\
\text { Konstruk }\end{array}$ & $\begin{array}{c}\text { Goodness of } \\
\text { Fit }\end{array}$ \\
\hline KK_3 & 0.834 & -2.15 & 0.57 & Kepuasan Kerja & 0,841 & \\
\hline KK_2 & 0.869 & 0.05 & 0.05 & $\begin{array}{l}\text { Komitmen } \\
\text { Organisasional }\end{array}$ & 0.794 & \\
\hline KO_14 & 0.653 & -1.78 & 0.58 & Referent Power & 0.579 & \\
\hline KO_13 & 0.566 & 0.12 & -1.93 & Kinerja & 0.789 & \\
\hline KO_8 & 0.636 & -1.44 & 2.19 & Chi Square-P & & 0.054 \\
\hline KO_6 & 0.664 & -1.88 & -1.27 & GFI & & 0.878 \\
\hline KO_2 & 0.679 & 0.90 & -2.45 & CMIN/DF & & 1.388 \\
\hline KO_1 & 0.552 & -0.86 & -1.14 & CFI & & 0.957 \\
\hline Kinerja_1 & 0.626 & 0.09 & 0.03 & IFI & & 0.959 \\
\hline Kinerja_2 & 0.787 & 0.29 & 0.97 & TLI & & 0.946 \\
\hline Kinerja_3 & 0.813 & -0.17 & 0.73 & RMSEA & & 0.058 \\
\hline $\mathrm{RP}_{-1}$ & 0.521 & -2.14 & 1.69 & & & \\
\hline $\mathrm{RP} \_2$ & 0.748 & 0.40 & 2.34 & & & \\
\hline $\mathrm{CC}$ & & -1.72 & -1.76 & & & \\
\hline
\end{tabular}

Sumber: Data primer yang diolah (2019)

\section{Pengujian Hipotesis}

Pada penelitian ini menggunakan alat analisis AMOS. Perhitungan hipotesis ini menggunakan nilai signifikansi sebesar $10 \%$. Jika nilai signifikansi $(\mathrm{p})<10 \%$, maka dapat disimpulkan bahwa hipotesis diterima dan begitu juga sebaliknya. Hasil pengujian hipotesis dapat dilihat pada table 4 .

Hipotesis 1 yaitu bahwa iklim peduli berdampak tidak langsung yang signifikan terhadap komitmen organisasional melalui peran mediasi kepuasan kerja. Hasil pengujian hipotesis pada tabel 4, menunjukkan bahwa persepsi responden dalam pengambilan keputusan untuk kesejahteraan bagi semua orang yang ada di organisasional memiliki pengaruh signifikan sebesar 0.070 terhadap persepsi responden mengenai keinginan tetap bekerja dan kepuasan terhadap pekerjaannya. Demikian juga, persepsi responden mengenai keinginan 
tetap bekerja dan kepuasan terhadap pekerjaannya memiliki pengaruh yang signifikan sebesar 0,000 terhadap persepsi responden mengenai keterikatan dan ketergantungan dengan organisasional. Oleh karena itu hipotesis 1 diterima. Jadi, semakin tinggi persepsi responden dalam pengambilan keputusan untuk kesejahteraan bagi semua orang yang ada di organisasional mempengaruhi persepsi responden terhadap keinginan tetap bekerja dan kepuasan terhadap pekerjaannya. Semakin tinggi persepsi responden mengenai keinginan tetap bekerja dan kepuasan terhadap pekerjaannya mempengaruhi persepsi responden mengenai keterikatan dan ketergantungan dengan organisasional.

Tabel 4. Pengujian Hipotesis

\begin{tabular}{|c|c|c|c|c|c|c|c|}
\hline & & & Estimate & S.E. & C.R. & $\mathrm{P}$ & Label \\
\hline KK & $<---$ & $\mathrm{CC}$ & .246 & .136 & 1.811 & .070 & par_9 \\
\hline KK & $<---$ & $\mathrm{RP}$ & 1.103 & .521 & 2.116 & .034 & par_15 \\
\hline $\mathrm{KO}$ & $<---$ & $\mathrm{CC}$ & .169 & .082 & 2.047 & .041 & par_10 \\
\hline $\mathrm{KO}$ & $<---$ & $\mathrm{KK}$ & .447 & .089 & 5.021 & $* * *$ & par_11 \\
\hline Kinerja & $<---$ & $\mathrm{KO}$ & .046 & .144 & .323 & .747 & par_12 \\
\hline Kinerja & $<---$ & $\mathrm{KK}$ & .406 & .115 & 3.534 & $* * *$ & par_13 \\
\hline
\end{tabular}

Sumber: Data Primer yang diolah (2019)

Hipotesis 2 yaitu bahwa iklim peduli berdampak tidak langsung dan signifikan terhadap kinerja karyawan melalui peran mediasi kepuasan kerja. Hasil pengujian hipotesis pada tabel 4, menunjukkan bahwa persepsi responden dalam pengambilan keputusan untuk kesejahteraan bagi semua orang yang ada di organisasional memiliki pengaruh signifikan sebesar 0.070 terhadap persepsi responden mengenai keinginan tetap bekerja dan kepuasan terhadap pekerjaannya. Dan juga, persepsi responden mengenai keinginan tetap bekerja dan kepuasan terhadap pekerjaannya memiliki pengaruh signifikan sebesar 0.000 terhadap persepsi responden mengenai seberapa baik hasil kinerja responden oleh responden, atasan, dan rekan kerja. Oleh karena itu hipotesis 2 diterima. Jadi, semakin tinggi persepsi responden dalam pengambilan keputusan untuk kesejahteraan bagi semua orang yang ada di organisasional mempengaruhi persepsi responden terhadap keinginan tetap bekerja dan kepuasan terhadap pekerjaannya. Semakin tinggi persepsi responden mengenai keinginan tetap bekerja dan kepuasan terhadap pekerjaannya mempengaruhi persepsi responden mengenai seberapa baik hasil kinerja responden oleh responden, atasan, dan rekan kerja.

Hipotesis 3 penelitian ini menduga bahwa iklim peduli berdampak tidak langsung terhadap kinerja karyawan melalui peran mediasi komitmen organisasional. Dari hasil pengujian hipotesis pada tabel 4, menunjukkan bahwa hipotesis 3 ditolak karena nilai signifikansi pengaruh persepsi responden mengenai keterikatan dan ketergantungan dengan organisasional terhadap persepsi responden mengenai seberapa baik hasil kinerja responden oleh dirinya sendiri, atasan, dan rekan kerja, lebih besar dari 0,100, yaitu 0,747. Artinya komitmen organisasi tidak memediasi pengaruh iklim peduli terhadap kinerja. 
Hipotesis 4 menyatakan bahwa kepuasan kerja berdampak tidak langsung yang signifikan terhadap kinerja karyawan melalui peran mediasi komitmen organisasional. Dari hasil pengujian hipotesis pada tabel 4 , menunjukkan bahwa hipotesis 4 ditolak dengan nilai signifikasi 0,747 untuk pengaruh persepsi responden mengenai keterikatan dan ketergantungan dengan organisasional terhadap persepsi responden mengenai seberapa baik hasil kinerja responden oleh dirinya sendiri, atasan, dan rekan kerja. Artinya, komitmen organisasional tidak memediasi pengaruh kepuasan kerja terhadap kinerja. Dengan kata lain, keinginan individu untuk tetap bekerja dan kepuasan terhadap pekerjaannya memiliki hubungan langsung dengan keterikatan dan ketergantungan individu dan seberapa baik hasil kinerja responden oleh responden, atasan, dan rekan kerja.

Hipotesis 5 menduga bahwa referent power berpengaruh terhadap kepuasan kerja. Hasil pengujian hipotesis pada tabel 4 , menunjukkan bahwa referensi responden dengan perilaku atasan berdasarkan nilai-nilai universitas memiliki pengaruh 4 terhadap keinginan untuk tetap bekerja dan kepuasan terhadap pekerjaannya, sehingga hipotesis 5 diterima. Semakin tinggi persepsi responden mereferensikan dirinya dengan perilaku pimpinan berdasarkan nilai-nilai universitas maka responden semakin memiliki keinginan tetap bekerja dan kepuasan terhadap pekerjaannya

\section{Pembahasan}

Lingkungan kerja di universitas yang mempertimbangkan kepentingan dosen dan tenaga kependidikan dalam pengambilan keputusan memberikan sarana bagi tumbuhnya kepedulian yang sama diantara dosen, tenaga kependidikan dan pengelola universitas. Kepedulian untuk membantu dalam setiap aktivitas penyelenggaraan dan pengelolaan pendidikan menciptakan kebiasaan bekerja sama untuk mencapai tujuan universitas. Keyakinan bahwa ada peluang dan bantuan yang akan diterima dalam setiap pekerjaan untuk mengembangkan kemampuan dalam mencapai tujuan, membuat dosen dan tenaga kependidikan memiliki perasaan nyaman dan keinginan untuk tetap bekerja di universitas. Aktivitas dosen dan tenaga kependidikan yang terbimbing dan terbantu karena iklim peduli ini membuat mereka puas terhadap pekerjaannya dan mau memiliki kinerja yang baik. Temuan ini mendukung hasil penelitian menurut Okpara \& Wynn (2012) yang menemukan bahwa iklim peduli memiliki dampak positif yang signifikan terhadap kepuasan kerja secara keseluruhan dan berbagai aspek kepuasan kerja termasuk promosi, pengawasan, rekan kerja, dan pekerjaan itu sendiri. Temuan ini juga mengkonfirmasi hasil penelitian $\mathrm{Fu}$ (2011) yang melaporkan bahwa aspek kepuasan kerja (gaji, rekan kerja, pengawasan, dan pekerjaan itu sendiri) memiliki dampak yang signifikan terhadap komitmen organisasi.

Penelitian ini menambahkan variabel referent power yang menjelaskan peran perilaku pemimpin sebagai sumber power. Perilaku positif pemimpin yang ditunjukkan dari luaran akademik yang dihasilkan, ketaatan terhadap peraturan, kedisiplinan, kejujuran, respek terhadap bawahan dan personaliti dapat menjadi sumber bagi pemimpin untuk mempengaruhi bawahan melakukan aktivitas yang mendukung pencapaian tujuan. Perilaku atasan menjadi referensi bagi dosen dan tenaga kependidikan untuk berperilaku. Data statistik deskriptif menunjukkan bahwa nilai rerata referent power dan kepuasan kerja yang tinggi. Temuan penelitian menyatakan bahwa perilaku dosen dan tenaga kependidikan yang mereferensi perilaku atasan berpengaruh terhadap kepuasan kerja. Hal ini menunjukkan bahwa mentoring seorang pemimpin menjadi sumber power yang mampu menggerakkan dosen dan bawahannya untuk memiliki perilaku yang sama denga pemimpin, sehingga memiliki keinginan untuk tetap bekerja dengan baik di universitas., mendukung 
Hasil pengujian hipotesis pertama dan ketiga menemukan bahwa kepuasan kerja dan iklim peduli memiliki pengaruh signifikan terhadap komitmen organisasi. Hal ini menunjukkan bahwa keterikatan dosen dan tenaga kependidikan dengan universitas dapat terbentuk dari iklim peduli yang membuat mereka nyaman dan puas terhadap pekerjaannya sehingga ingin tetap tinggal untuk bekerja di universitas. Temuan menarik dalam penelitian adalah komitmen organisasi yang tidak memiliki pengaruh terhadap kinerja. Statistik deskriptif dalam tabel 2 menunjukkan bahwa rerata komitmen organisasi dan kinerja dosen dan tenaga kependidikan tinggi. Artinya dosen dan tenaga kependidikan memiliki keterikatan yang tinggi terhadap universitas, tetapi keterikatan ini tidak berpengaruh terhadap kinerja, sehingga peran komitmen organisasi sebagai variabel mediasi dalam penelitian ini tidak terbukti. Kinerja yang ditetapkan di universitas ini adalah kinerja minimal yang harus dipenuhi oleh dosen dan tenaga kependidikan. Penetapan kinerja ini akan mendorong dosen dan tenaga kerja untuk memenuhi target kinerja minimal tersebut. Hal ini tampak pada rerata kinerja yang tinggi, karena target minimal pasti tercapai.

Berbeda dengan komitmen organisasi, kepuasan kerja yang mengindikasikan keinginan dosen dan tenaga kependidikan untuk tetap bekerja di universitas dan perasaan puas terhadap pekerjaannya, memiliki peran mediasi pada pengaruh iklim peduli terhadap kinerja dosen dan tenaga kependidikan. Artinya kepedulian antar dosen dan tenaga kependidikan mempengaruhi proses belajar dan pengembangan kemampuan mereka, sehingga mereka dapat mengerjakam pekerjaan dengan lebih baik dan lebih mudah. Bantuan dan melakukan pekerjaan secara bersama dan terbimbing akan membuat dosen dan tenaga kependidikan memiliki keinginan untuk tetap bekerja di universitas. Keberadaan dosen dan tenaga kependidikan yang memiliki kemampuan yang baik akan berpengaruh pada capaian kinerja dengan luaran yang baik pula. Hasil penelitian ini mendukung temuan penelitian Okpara \& Wynn (2012), Fu dan Dispande (2014) dan Noor (2016).

\section{SIMPULAN}

Penelitian ini memberikan penjelasan bahwa iklim peduli memberikan peran dalam membentuk sikap, kepuasan kerja dan komitmen, dan perilaku positif individu, yaitu kinerja, dengan memberikan media berupa kepedulian yang memungkinkan semua individu memiliki kesempatan untuk belajar dan memiliki kemampuan yang dibutuhkan untuk mencapai tujuan organisasi. Iklim kepedulian membentuk perilaku positif individu, bukan melalui penetapan kode etik tetapi melalui perilaku etis yang memungkinkan semua individu untuk memiliki perilaku yang memberikan benefit bagi setiap individu di dalam organisasi. Kepedulian memberikan kesempatan individu untuk belajar, mengembangkan diri sehingga nyaman dan mampu melakukan pekerjaannya dengan baik. Peran pemimpin sebagai role model akan membuat bawahan mereferensi perilaku atasan dengan melakukan perilaku yang sama. Peran pimpinan dan iklim peduli menjadi alasan bagi individu untuk tetap tinggal dalam organisasi.

Temuan penelitian ini tidak dapat membuktikan bahwa komitmen memediasi efek iklim kepedulian terhadap kinerja individu. Hal ini mengindikasikan bahwa kepedulian dalam proses belajar dan berkembang dalam universitas ini tidak membuat individu memiliki keterikatan dengan universitas ini, meskipun mereka memiliki kinerja yang baik.

Penelitian ini memiliki implikasi dan saran penting bagi universitas yang menjadi objek penelitian ini adalah iklim kepedulian yang sudah dimiliki oleh universitas ini harus diperlihara dengan baik. Sistem mentoring yang berkelanjutan akan membangun kepedulian 
antar individu untuk memiliki kemampuan dan mencapai kinerja yang baik. Hal penting untuk diperhatikan adalah keterikatan individu dengan universitas. Secara rerata, komitmen individu terhadap universitas ini tinggi, tetapi tidak memiliki pengaruh signifikan terhadap kinerja. Analisis yang dilakukan mengarahkan pada penentuan target minimal yang menjadi standar kinerja bukan penetapan tujuan yang menjadi target kinerja. Hal ini membuat kinerja pasti tercapai.

Meskipun penelitian memberikan kontribusi dengan mengaplikasikan model $\mathrm{Fu}$ dan Despande (2014) di sektor pendidikan, tetapi enelitian ini memiliki keterbatasan karena menggunakan objek satu universitas saja, sehingga validitas eksternal untuk penelitian di ranah pendidikan rendah. Penelitian serupa dengan menggunakan bentuk iklim etis lain dapat menjadi peluang bagi penelitian selanjutnya.

\section{DAFTAR PUSTAKA}

Bangun W. 2012. Manajemen Sumber Daya Manusia. Jakarta: Penerbit Earlangga.

Biong, H., A. Nygaard, dan R. Silkoset. 2010. The Influence of Retail Management' s Use of Social Power on Corporate Ethical Values, Employee Commitment, and Performance. Journal of Business Ethics. 97: 87-108.

Carolina, Y. A. 2012. The Influence of Ethical Climate toward Organizational Commitment and Turnover Intention, (Case Study : PT. TRAC Cikarang), Depok: Universitas Indonesia.

Dewi, A. R. S., dan H. Nita. 2018. Pengaruh Gaya Kepemimpinan, Budaya Organisasional dan Komitmen Organisasional Terhadap Kinerja Pegawai Dinas Pertanian Kabupaten Mamuju. Jurnal Bisnis, Manajemen, dan Informatika. 14(2): 92-102.

Dinc, M. Sait dan V. Plakalovic. 2016. Impact of Caring Climate, Job Satisfaction, and Affective Commitment on Employees' Performance in the Banking Sector of Bosnia and Herzegovina. Eurasian Journal of Business and Economics. 9 (18): 1-16

Djastuti, I., dan I. Yudayanti. 2010. Analisis Pengaruh Faktor-Faktor Leader Power Terhadap Kepuasan Kerja (Studi Kasus Pada Tiga Perusahaan Asuransi Jiwa Di Semarang). Jurnal Studi Manajemen dan Organisasional (JSMO). 2(1): 120-137.

Fu, W., dan S. P. Deshpande. 2012. Antecedents of Organizational Commitment in a Chinese Construction Company. Journal of Business Ethics. 109: 301-307.

Fu, W., dan S. P. Deshpande. 2014. The Impact of Caring Climate, Job Satisfaction, and Organizational Commitment on Job Performance of Employees in a China's Insurance Company. Journal of Business Ethics. 124(2): 339-349.

Fu, W., S. P. Deshpande, dan X. Zhao. 2011. The Impact of Ethical Behavior and Facets of Job Satisfaction on Organizational Commitment of Chinese Employees. Journal of Business Ethics. 104: 537-543.

Ghozali, I. 2017. Model Persamaan Struktural: Konsep dan Aplikasi dengan Program Amos 24 Edisi 7. Semarang: Universitas Diponegoro. 
Goldman, A., and N. Tabak.2010. Perception of ethical climate and its relationship to nurses' demographic characteristics and job satisfaction. Nursing Ethics, 17(2): 233-246

Jamal, M. 2011. Job stress, job performance and organizational commitment in a multinational company: An empirical study in two countries. International Journal of Business and Social Science. 2(20): 20-29.

Kudisch, J. D., M. L. Poteet, G. H. Dobbandns, M. C. Rush, dan J. E. A. Russell. 2010. Expert power, referent power, and charisma: Toward the resolution of a theoretical debate. Journal of Business and Psychology. 10(2): 177-195.

Laratta, R. 2009. Ethical Climate in Nonprofit Organizations: A Comparative Study. International Journal of Sociology and Social Policy. 29(7/8): 358-371.

Mangkunegara, A. P. 2009. Manajemen sumber daya manusia perusahaan. Bandung: PT. Remaja Rosda Karya.

Mathis, R. L., and J. H. Jackson. 2010. Human Resource Management. Edisi 13. Jakarta: Salemba Empat.

Meeusen, V. C. H., Dam, K. V. Brown-Mahoney, C., Zundert, A. J. V., and H. T. A. Knape. 2011. Work climate related to job satisfaction among Dutch nurse anesthetists. AANA Journal, 79(1): 63-70

Noor, N. N., K. Rahardjo, dan I. Ruhana. 2016. Pengaruh Stres Kerja Dan Kepuasan Kerja Terhadap Kinerja Karyawan (Studi Pada Karyawan PT JasaRaharja (Persero) CabangJawaTimur di Surabaya). Jurnal Administrasi Bisnis. 31(1): 9-15.

Nurandini, A., dan E. Lataruva. 2014. Analisis pengaruh komitmen organisasional terhadap kinerja karyawan (Studi Pada Pegawai Perum PERUMNAS Jakarta). Jurnal Studi Manajemen dan Organisasional. 11: 78-91

Okpara, J. O., and P. Wynn. 2012. The impact of ethical climate on job satisfaction , and commitment in Nigeria Implications for management development. Journal of Management Development. 27(9): 935-950.

Parboteeah, K. P., H. C. Chen, Y.T. Lin, H. Chen, A. Y. P. Lee, and A. Chung. 2010. Establishing Organizational Ethical Climates: How Do Managerial Practices Work. Journal of Business Ethics. 97(4): 599-611.

PDDikti. 2019. Statistik Pendidikan Tinggi, Jakarta: Kementerian Riset, Teknologi dan Pendidikan Tinggi.

Riaz, K. M. 2010. The impacts of organizational commitment on employee job performance. European Journal of Social Science. 15(3): 292-298

Robbins, S.P., dan T. Judge. 2011. Organizational behavior (14th ed.). New Jersey: Prentice Hall.

Robins, C. 2010. Manajemen. Jakarta: Penerbit Erlangga.

Rosyidah, E., I. Fadah, dan D. S. K. Tobing. 2018. Pengaruh Kepuasan Kerja dan Budaya 
Organisasional Terhadap Kinerja Pegawai Melalui Komitmen Organisasional di UnitUnit Pelayanan Publik Kabupaten Jember. Relasi:Jurnal Ekonomi. 14(1): 1-16.

Saragih, A. Y., E. S. Astuti, dan M. Djudi. 2018. Pengaruh Kepuasan Kerja Terhadap Motivasi Kerja dan Kinerja Karyawan (Studi pada karyawan tetap di Pabrik Gula Kebon Agung Malang). Jurnal Administrasi Bisnis. 61(2): 202-209.

Sinulingga, A. C., dan D. Aseanty. 2018. Peran Kepuasan Kerja dan Komitmen Afeksi Antara Caring Climate Dengan Kinerja Karyawan. Jurnal Manajemen dan Pemasaran Jasa. 10(2): 187-200.

Sugiyono. 2010. Metode Penelitian Bisnis. Cetakan Kelimabelas. Alfabeta. Bandung.

Supardi. 2013. Kinerja Guru. Jakarta : PT Raja Grafindo Persada.

Sutrisno, E. 2012. Sumber Daya Manusia. Surabaya: Gramedia

Thomas, T. P. 2013. The effect of personal values, organizational values, and personorganization fit on ethical behaviors and organizational commitment outcomes among substance abuse counselors: A preliminary investigation. $\mathrm{PhD}$ thesis: University of Iowa,

Tsai, M. T., dan H. C. Chen. 2011. The relationship among ethical climate types, facets of job satisfaction, and the three components of organizational commitment: A study of nurses in Taiwan. Journal of Business Ethics. 80(3): 565-581.

Umam, K. 2012. Perilaku Organisasional. Bandung: CV. Pustaka Setia.

Valentine, S., and T. Barnett. 2003. Ethics code awareness, perceived ethical values, and organizational commitment. Journal of Personal Selling \& Sales Management. 23(4): 359-367.

Yuliana, M., H, L. Budi, dan E. Gagah. 2017. Pengaruh Lingkungan Kerja, Disiplin Kerja, Dan Kepuasan Kerja Terhadap Kinerja Karyawan BMT Taruna Sejahtera Ungaran. Journal of Management. 3(3): 1-11. 